\title{
Revaluation of bamboo as biomass
}

\author{
Nicoleta Alexandra Vanghele ${ }^{1, *}$, Andreea Matache ${ }^{1}$, Mariana Mădălina Stanciu ${ }^{1}$, and \\ Dumitru Bogdan Mihalache ${ }^{1}$ \\ ${ }^{1}$ INMA National Institute of Research - Development for Machines, and Installations \\ designed to Agriculture and Food Industry, Bucharest
}

\begin{abstract}
Bamboo is a grassy plant that grows rapidly, is also a renewable natural resource and with a high yield. There are many applications and uses of bamboo, which led to its planting around the world. Among the industries in which bamboo has by now experienced extensive exploitation, we can remember the textile, construction, furniture ; even food, pharmaceutical or cosmetic industries.

Biomass is the plant material that is used as a renewable energy resource. This is achieved others by cultivating plants specially used for energy production or by using resistors from small industrial sectors.

The current paper highlights the potential for the recovery of bamboo as biomass, both in terms of the fact that bamboo is a plant that is believed to be an inexhaustible resource, but also for the wide amount of rest from its multiple uses.
\end{abstract}

Keywords : bamboo, biomass, renewable resource, residues

\section{Introduction}

In recent decades, there has been a tendency to exploit biomass sources to replace traditional fossil fuels. Such a material capable of producing large amounts of biomass is the bamboo [1].

Biomass (vegetable material) is a renewable energy source which becomes more competitive compared to traditional energy production sources in terms of system installation expenses and energy production costs [1]. Biomass stores the energy it receives from the Sun using the process called photosynthesis. In biomass processing, whether it is incineration, pyrolysis or gasification, there is a release of the energy captured from the Sun and its transformation into other forms of energy. From this perspective, biomass can be seen as an accumulator that can store solar energy for long periods. [2]. Unlike batteries, however, biomass is a sustainable source of energy storage, and if sustainable crop management methods are applied, it is unlimited. Generally, there are two main approaches to the use of plants to produce energy (1) the cultivation of plants specifically for the use of energy and (2) the use of residues resulted from agricultural practices [3]. The best

\footnotetext{
* Corresponding author : vanghelelrc@,gmail.com
} 
approach varies, depending on several factors such as climate, soils and geographical conditions [4].

Biomass may be considered an abundant source of energy because covers a large part of land surfaces and has a short life cycle, being an important candidate as an alternative fuel.

Energy crops are identified with the cultivation of annual or sustainable plants, at the industrial level, which are intended to provide biomass used to obtain various energy sources. Compared to other renewable sources of bioenergy such as wind powe or photovoltaic power, the energy produced from biomass is an intermitted energy source in nature, but can easily be stored in solid, liquids or gaseous forms. From this issue it can be concluded that bioenergy is a stable resource of auxiliary energy [5].

Bamboo is part of the Poaceae family, as well as corn, wheat, sugar cane, barley, oats, rye and rice. It can have up to 1250 species from 75 genres and is spread around the world [6].

The bamboo plants are fast-growing plants, representing a renewable and high-yield natural resource.

Bamboo is known as "the plant of a thousand uses", since plays an important socioeconomic role, being also related to humanity since ancient times [7].

Bamboo has common characteristics with many other biomass raw materials in terms of the heating value and chemical composition. The commonly used conversion technologies of waste to energy involves the transformation of the row material into other forms of fuels [8]. The bamboo characteristics may differ depending on the species, plant section, the maturity of the plants, the season, or cultivation practices (e.g. fertilizer) and place of production [9].

This paper is a brief synthesis of the highlighter of the biomass potential of bamboo studied in literature.

\section{Materials and methods}

In the process of obtaining the carbohydrates that form the building blocks" of biomass, the $\mathrm{CO}_{2}$ in the atmosphere, water and in the soil participate. If chemical energy is extracted (biomass is burned), oxygen from the atmosphere and carbon from plants react by forming carbon dioxide and water (fig.1). Since carbon dioxide can participate again in the biomass formation process, the process is cyclical [10].

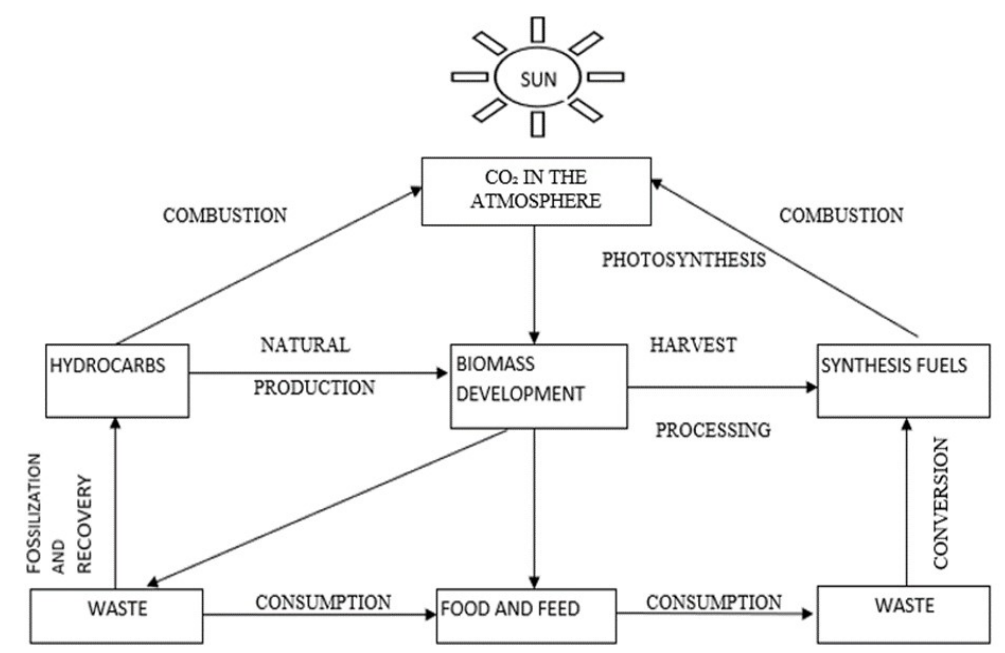

Fig. 1. Biomass formation [8]. 
The elemental composition of vegetable biomass is shown in Figure 2. The size of the boxes corresponded to the amount of each element in the composition of biomass.

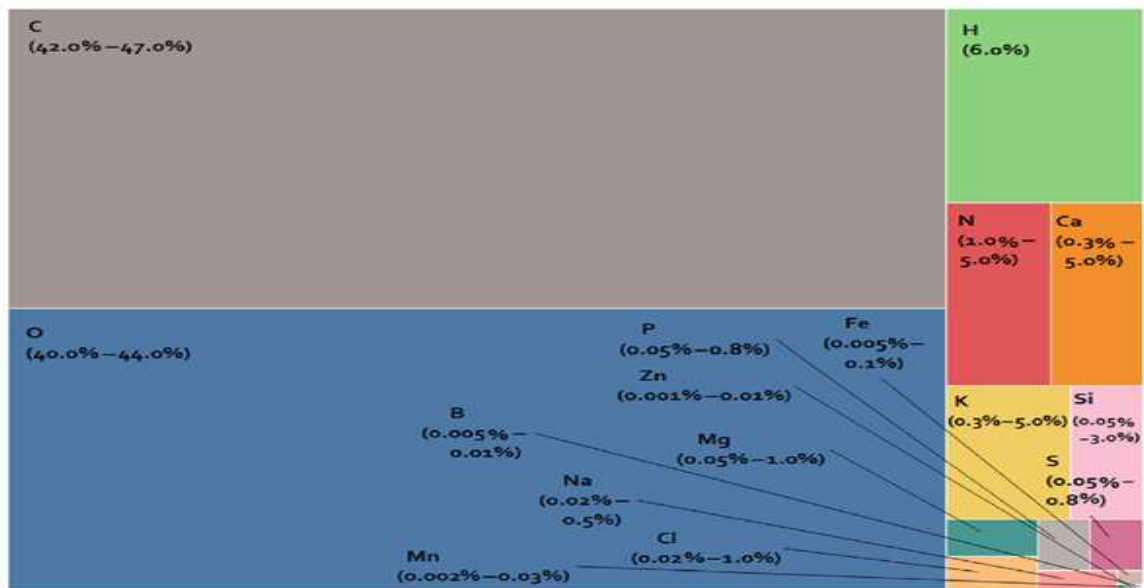

Fig. 2. Elemental composition of plant biomass. (\%) [11].

The general composition and heating value of bamboo is found between the values of wood and the herbaceous material. The woody bamboo peaks, that are mature and dry, is considered the most suitable bio-fuel.

Bamboo presents several advantages compared to other lignocellulosic raw materials. The most important advantages are the higher crop yields and higher biomass densities both being important features that may lead to lower production and transport costs. In addition, bamboo cropping doesn't need the utilization of seeds and plastics for baling. The total amounts of fertilizers required by the crops are also relatively low. These are key benefits in terms economy and of biomass value.

Table 1 shows the average characteristics of the plant compared to other biomass raw materials, that have been found in the literature [8].

Table 1. Biomass properties of bamboo compared to specific raw materials.

\begin{tabular}{|l|l|l|l|l|l|}
\hline \multicolumn{2}{|l|}{ Raw } & Bamboo culm & Cane bag & $\begin{array}{c}\text { Wheat } \\
\text { straw }\end{array}$ & Wood \\
\hline $\begin{array}{l}\text { Higher heating } \\
\text { value (dry) }\end{array}$ & $\mathrm{MJ} \mathrm{kg}^{-1}$ & $17-20$ & $18-20$ & $16-19$ & $17-20$ \\
\hline Bulk density & $\mathrm{kg} \mathrm{m}^{-3}$ & $300-700$ & $150-200$ & $160-300$ & $200-500$ \\
\hline Crop yield & $\begin{array}{l}\text { Ton } \\
\text { ha/year }\end{array}$ & $10-40$ & $7-15$ & $3-12$ & $5-20$ \\
\hline Cellulose & $\%$ & 40 & 35 & 38 & 50 \\
\hline Hemicellulose & $\%$ & 20 & 25 & 36 & 23 \\
\hline Lignin & $\%$ & 20 & 20 & 16 & 22 \\
\hline Others & $\%$ & $2-10$ & 20 & 10 & 5 \\
\hline
\end{tabular}

Bamboo affinity for energy pride. 


\section{Methods for producing energy from bamboo crops biomass}

Apart from transesterification technique, transformation of waste biomass to energy is carried out using thermochemical and biochemical conversion [12]. There are many procedures to recover energy from bamboo biomass.

\section{Thermochemical conversion can be performed:}

- By direct combustion.

Direct combustion furnaces might be used for direct heat technologies, or for creating steam. Dry bamboo may be used for direct combustion in small incineration units or on industrial scale. The principle of combustion consists of burning the fuel, that is composed mainly of carbon and hydrogen atoms under controlled conditions.

- By pyrolysis processes,

Pyrolysis is the phenomenon of thermal decomposition of biomass into highly heterogeneous gaseous, liquid, and solid intermediates, in the absence of oxygen. Therefore, it is a thermal degradation of organic materials at a temperature of 350 to 600 ${ }^{\circ} \mathrm{C}$. The main products produced from the pyrolysis process consist of coal (which is the solid phase of the obtained product), condensable oils (heavy hydrocarbons), tars (which is the liquid phase) and the condensable gases (which is called the gaseous phase). The pyrolysis is usually performed accordingly to the processes found in Figure 3 [13].

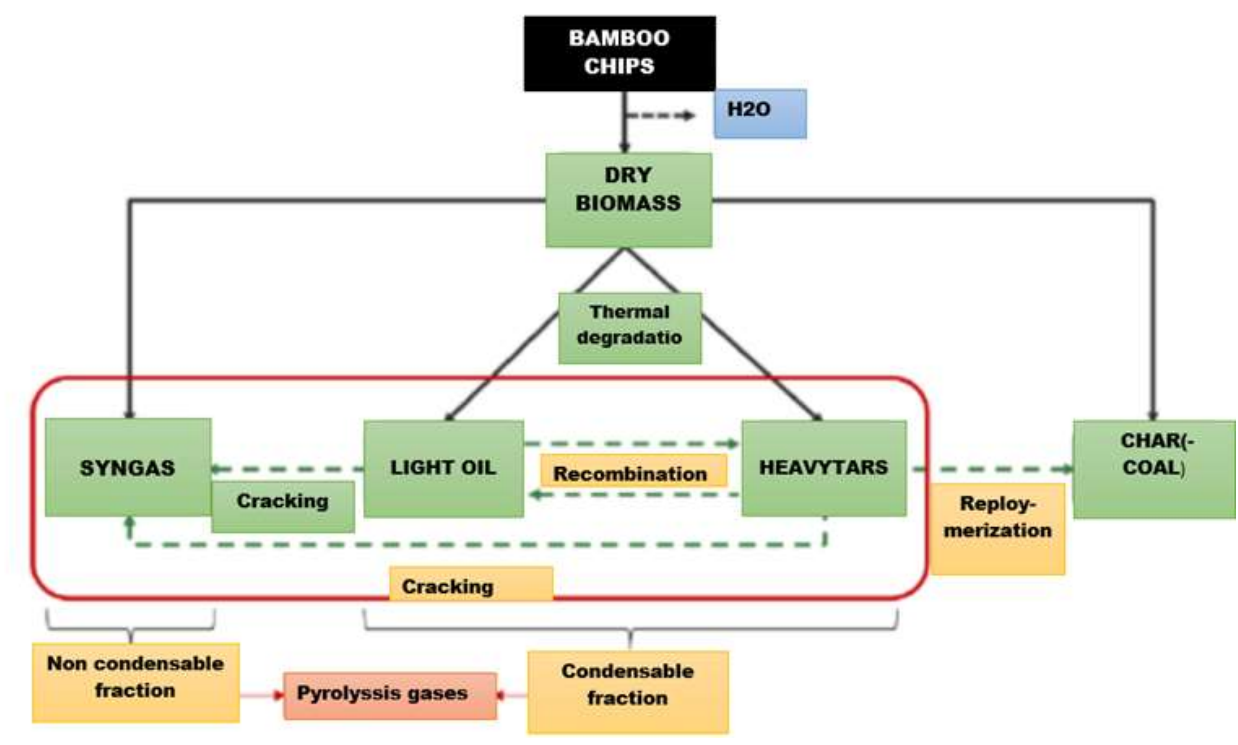

Fig. 3. The diagram depicting combustion process of bamboo biomass [13].

- By gasification

Gasification is the conversion of biomass- or fossil fuel-based carbonaceous materials into gases, such as: nitrogen (N2), carbon monoxide (CO), hydrogen (H2), and carbon dioxide (CO2). Gasification consists in a process of thermal and chemical conversion of organic material at increased temperature under special air intake conditions. The gasification process may include pyrolysis and partial combustion, occurring at a high temperature, usually between $750{ }^{\circ} \mathrm{C}$ and $1200{ }^{\circ} \mathrm{C}$.

The gasification process will have as products syngas and ash. The gaseous products are usually named syngas, and can be either used directly in the burners, or are desulfurized 
and used in internal combustion engines. Syngas is a mixture of combustible gases and noncombustible gases. Approximately $40 \%$ of the volume of syngas can be used for generating electricity or heat. In practice atmospheric air is normally used since oxygen is quite expensive.

\section{Biochemical conversion}

In biochemical conversion, different strains of microorganisms that convert various products from biofuels are used. The principle of biochemical conversion is the fermentation of sugars and other substances contained in biomass. The processing is performed with the help of microorganisms which will produce different amounts of ethanol, methane and other fuels, chemical and thermal.

Bioconversion can be performed either in the presence of air or in its absence:

- Anaerobic digestion (Figure 4) is a process through which bacteria break down organic matter (animal manure, wastewater biosolids, and food wastes) in the absence of oxygen, producing biogas (methane) (60\%) and CO2 (40\%) [14].

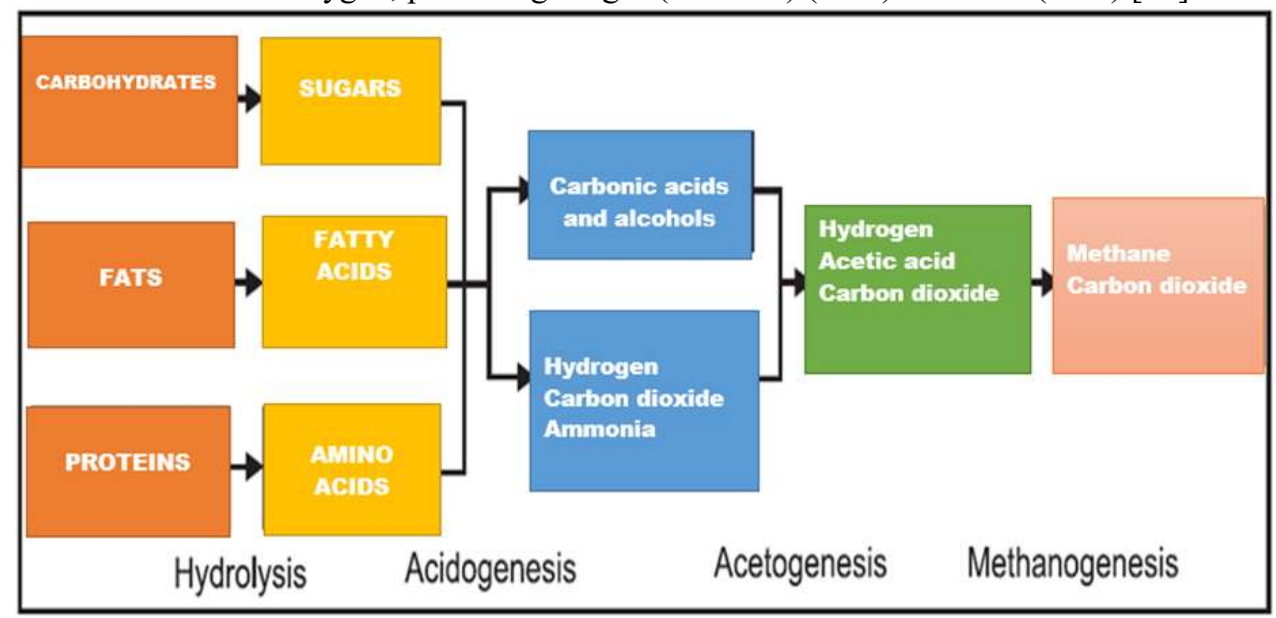

Fig. 4. Anaerobic digestion path [11].

- Fermentation usually occurs in the presence of oxygen being the decomposition of starch/sugar by microorganisms (yeasts and bacteria) to produce ethanol. By pretreatment with acid and enzyme at high processing temperatures, bamboo biomass turns into cellulose, which by hydrolysis becomes sugar which after fermentation turns into ethanol

Bamboo $\rightarrow$ Biomass $\rightarrow$ Cells $\rightarrow$ Sugar $\rightarrow$ Ethanol.

Liquid fraction, also called the pyrolysis fuels is processed into a biorefinery to produce biofuels. Syngas is usually burned in cogeneration plants for the production of energy and electricity. In biochemical conversion, are usually used several different strains of microorganisms to convert biomass into biofuels. The technological flow involves the fermentation of sugars or other substances from bamboo biomass into (bio) ethanol, methane and other fuels.

Furthermore, bamboo has attractive fuel production characteristics, the most important parameters being the high heat values, the high volatile contents, the low ash and moisture 
content. This is why bamboo is considered an appropriate crop for production of bioenergy [15].

\section{Results and discussions}

Over the years, tests have been conducted to assess the energy potential of bamboo. Several research studies on this subject are highlighted in the following.

At Hasanuddin University, Tamalanrea, Makassar, Indonesia, the energy potential of bamboo leaf biomass has been verified.

In this study, bamboo leaves were used to conduct experiments according to temperature and heating time. Proximal analyses were used to determine first the volatile matter (VM). The ash content, the fixed carbon (CF) and moisture content (MC) have been also determined.

Have been used three prediction formulas to estimate the content of carbon, hydrogen and oxygen.

The dried bamboo leaves have been cleaned using distilled water, then a cutting process was applied, shredded and sifted at $500 \mu \mathrm{m}$ until homogenized, after which they were heated to $250{ }^{\circ} \mathrm{C}, 300{ }^{\circ} \mathrm{C}$, and $350^{\circ} \mathrm{C}$ for 30,60 and 90 minutes in - an environment devoid of oxygen.

The results of Table 2 [16] were obtained from the analyses.

Table 2. Main parameters obtained in percentages from bamboo leaves.

\begin{tabular}{|c|l|l|l|l|l|}
\hline $\begin{array}{l}\text { Temperature } \\
\left({ }^{\circ} \mathbf{C}\right)\end{array}$ & $\begin{array}{l}\text { Time } \\
(\mathbf{m i n})\end{array}$ & $\begin{array}{l}\text { Moisture } \\
\text { content }(\mathbf{\%})\end{array}$ & $\begin{array}{l}\text { Volatile } \\
\text { matter (\%) }\end{array}$ & $\begin{array}{l}\text { Ash } \\
\text { content } \\
(\%)\end{array}$ & $\begin{array}{l}\text { Fixed } \\
\text { carbon } \\
(\%)\end{array}$ \\
\hline \multirow{3}{*}{250} & 30 & 2.72 & 32.21 & 34.15 & 30.57 \\
\cline { 2 - 6 } & 60 & 2.88 & 30.46 & 41.66 & 24.81 \\
\cline { 2 - 6 } & 90 & 4.40 & 38.22 & 32.27 & 24.63 \\
\hline \multirow{3}{*}{300} & 30 & 6,63 & 29.71 & 36.64 & 27.35 \\
\cline { 2 - 6 } & 60 & 2.31 & 31.22 & 42.27 & 24.45 \\
\cline { 2 - 6 } & 90 & 3.50 & 28.33 & 45.70 & 22.26 \\
\hline \multirow{3}{*}{350} & 30 & 2.40 & 25.94 & 50.10 & 21.40 \\
\cline { 2 - 6 } & 60 & 1.96 & 28.59 & 60.43 & 9.17 \\
\cline { 2 - 6 } & 90 & 2.87 & 22.32 & 71.37 & 3.89 \\
\hline
\end{tabular}

Bambusa vulgaris has been found to have characteristics that make it possible to use it as a primary fuel. Biomass consisting of strains of Bambusa vulgaris, without branches, has a high quality as it progresses from base to top and is between 1 and 3 years old. This observation is mainly due to the energy density analysis, which has higher values in the upper position and at the age of three.

The quality of the biomass Bambusa vulgaris as an energy intake improves with increasing age and in the upper parts of the stems, producing a greater amount of energy per unit of volume. 
The energy quality of Bambusa vulgaris was also investigated. Research has established that this species has a moisture content close to the maximum to generate energy (30\%) 20.19\%. In addition, the species under analysis can be used to increase the biomass base for energy production and to replace the wood that is used on large scale for this purpose [17].

Usually, the yield of bamboo biomass is no different within aspecies. However, following a fight at two locations in Thailand on two bamboo species, namely Bamboo becheyana and Dendrocalamus membranaceus, it was found that they may differ. As regards species $D$. membraneaceus the moisture content is lower while the calorific power is higher than that of species $B$. beecheyana, indicating that $D$. membranaceus. may be a more attractive option as a raw material for obtaining biomass [18].

\section{Conclusions}

Since bamboo is a very common plant used in different industries, this certainly leads to the production of numerous plant residues. They can be harnessed as biomass.

Over the years many researchers have studied the potential of bamboo to devein biomass and have shown that it lends itself to being a good raw material for the generation of plant biomass.

From the literature we can conclude that fossil fuels can be replaced with bamboo biomass, which is renewable and capable of producing different types of fuels, be they solid, liquid or gaseous.

For the transformation of bamboo biomass into another form of energy can be applied various technologies. These transformations provide new products such as coal, syngas, oil and ethanol.

Unlike wind and photovoltaic energy in addition to electricity production, bamboo biomass also produces biofuels.

As disadvantages we can say that bamboo biomass brings environmental risks by decreasing biodiversity, invasion of species and takes a long time to mature.

Although much research has been done in the field, in many countries energy projects from bamboo biomass are still being implemented.

To evaluate he sustainable mode of use and the capacity of this resource are necessary much more mute specialized studies.

This work was upheld by one establishing NUCLEU Program, carried out with the support of ANCSI, Project PN 5N/07.02.2019 "Research on the superior valorisation of some new plants species cultivated in Romania".

\section{References}

1. F. Nenciu and V. Vlăduţ, Studies on the perspectives of replacing the classic energy plants with Jerusalem artichoke and Sweet Sorghum, analyzing the impact on the conservation of ecosystems, IOP Conf. Ser.: Earth Environ. Sci. 635 012002, (2021);

2. F. Song, Bamboo Neosinolamus affinis-based thin film, a novel biomass material with high performances, (2014);

3. F. Nenciu, G. Găgeanu, V.N. Vlăduț, M.G. Matache, I. Găgeanu, I. Voicea, G. Milian. Mircea C., Research on the use of technical plants and pomiculture waste in the production of biofuels, ISB INMA Teh (2020);

4. J. Piggot, Biomass supply economics: managing the supply cost of raw materials, TAPPI International Bioenergy and Bioproducts Conference, Memphis, TN; pp.14-16, (2009) pp.14-16;

5. ***Union of Concerned Scientists, How biomass energy works, (2009); 
6. W.H. Chen et al., Progress in biomass torrefaction: Principles, applications and challenges, Progress in Energy and Combustion Science, 82, January (2021);

7. M.F. Silva, et al., Bamboo as an eco-friendly material for food and biotechnology industries, Current Opinion in Food Science, (2020);

8. F. Nenciu, V. Vlăduţ, I. Voicea, I. Gageanu, Thermochemical conversion technologies for producing biofuels from agricultural biomass, Analele Universităţii din Craiova, seria Agricultură - Montanologie - Cadastru (Annals of the University of Craiova Agriculture, Montanology, Cadastre Series), Vol. L (2020);

9. A. Gupta, A. Kumar, The potential of the bambas in the sustainable development of AsiaPac. In your sea. Rev., 4 (2008), pp. $100-107$;

10. J.M.O. Scurlock, D.C Dayton, B. Hames, Bamboo: an overlooked biomass resource? , 19 Biomass and bioenergy (2000), pp 229-244;

11. A. Balázsi, Biomass as a source of renewable energy, analysis of energy technology from it, (2013);

12. J. Sánchez, et al. The Role of Bioenergy in the Bioeconomy, Biomass Resources, (2019) pp. 25-111;

13. D.R. Kerlero, J. Electrical Valorization of Bamboo in Africa; ENEA Consulting: Paris, France (2012);

14. J.E. Girard, Principles of Environmental Chemical, Jones \& Bartlett Publishers, (2013);

15. R. Kumar, N. Chandrashekar, Fuel properties and combustion characteristics of some promising bamboo species in India. J. For. Res. 25, (2014) pp.471-476;

16. A. Bidayatul, et al., Potentials of Biochars Rived from Bamboo Leaf Biomass as Energy Sources: Effect of Temperature and Time of Heating, Publishing International Journal of Biomaterials, (2019);

17. A.L. Balduino Junior et al. Energetic potential of bamboo culms for industrial and domestic use in Southern Brazil, Cienc. Rural 46 no. 11 Santa Maria, (2016);

18. A.Darabant, M. Haruthaithanasana et. al., Bamboo biomass yield and feedstock characteristics of energy plantations in Thailand, European Geosciences Union General Assembly, Energy Procedia 59 (2014) pp134 - 141; 